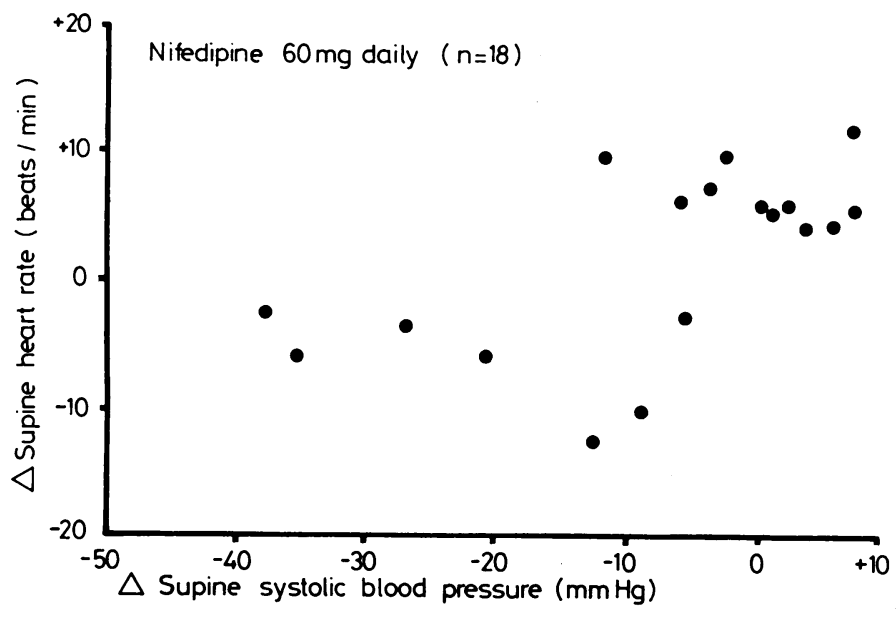

Supine heart rate versus supine systolic blood pressure: change from placebo to nifedipine ( $60 \mathrm{mg} / \mathrm{day})$.

In our previous report ${ }^{4}$ we showed that both nifedipine and propranolol were effective in managing angina of effort but that the combination was significantly better than either drug alone. Though it has been suggested that a reduction in blood pressure in patients with coronary artery disease may precipitate angina or ischaemia by reducing myocardial blood flow, the phase which produced the greatest fall in blood pressure also produced the greatest reduction in angina. Hypertension and ischaemic heart disease often co-exist and hypertension predisposes to and possibly aggravates atherosclerotic vascular disease. ${ }^{12} \mathrm{~A}$ regimen that lowers blood pressure and effectively improves ischaemia is thus advantageous. The combination of propranolol and nifedipine satisfies this need.

The hypotensive potential of beta-blocking agents was first noted during a clinical trial of propranolol in patients with angina pectoris. ${ }^{13}$ The favourable haemodynamic responses to calcium antagonists will probably also prove valuable in managing patients with hypertension.

Requests for reprints should be sent to Dr D M Krikler.

\section{References}

${ }^{1}$ Fleckenstein A. Specific inhibitors and promoters of calcium action in the excitation-contraction coupling of heart muscle and their role in the prevention or production of myocardial lesions. In: Harris $P$ Opie LH, eds. Calcium and the heart. London, New York: Academic Press, 1971:135-8.

${ }^{2}$ Fleckenstein A. Specific pharmacology of calcium in myocardium, cardiac pacemakers and vascular smooth muscle. Annu Rev Pharmacol Toxicol 1977;7:149-66.

${ }^{3}$ Wei JW, Jarvis RA, Daniel EE. Alterations in calcium transport and binding by the plasma membrane of mesenteric arteries from spontaneously hypertensive rats. Blood Vessels 1977;14:55-64.

${ }^{4}$ Lynch P, Dargie H, Krikler S, Krikler D. Objective assessment of anti-anginal treatment: a double-blind comparison of propranolol, nifedipine and their combination. $\mathrm{Br}$ Med f 1980;280:184-7.

${ }^{5}$ Armitage P. Statistical methods in medical research. Oxford: Blackwell Scientific, $1971: 266$

- MacGregor GA. Evidence from studies with nifedipine of a functional abnormality of smooth muscle in essential hypertension. In: Richardson RG, ed. National cardiovascular symposium: the role of calcium antagonists in cardiovascular disease. Haywards Heath: Bayer UK, 1982.

${ }^{7}$ Guazzi M, Olivari MT, Polese A, et al. Nifedipine, a new antihypertensive agent with rapid action. Clin Pharm Ther 1977;22:528-32.

${ }^{8}$ Rowland E, Evans T, Krikler D. Effect of nifedipine on atrioventricular conduction as compared with verapamil. Br Heart $\mathcal{f} 1979 ; 42: 124-7$.

- Kawai C, Kanishi T, Matsuyama E, Okazaki H. Comparative effects of three calcium antagonists, diltiazem, verapamil and nifedipine, on the sinoatrial and atrioventricular nodes. Circulation 1981;63:1035-42.

${ }^{10}$ Bristow JD, Honour AJ, Pickering G, Sleight P, Smyth HS. Diminished baroreflex sensitivity in high blood pressure. Circulation 1969;39:48-54.

11 Eckberg DL, Drabinsky M, Braunwald E. Defective cardiac parasympathetic control in patients with heart disease. $N$ Engl $f$ Med $1971 ; 285: 877-83$

${ }^{12}$ Kannel WB. Role of blood pressure in cardiovascular disease: The Framingham study. Angiology $1975 ; 26: 1-14$.

13 Prichard BNC, Gillam PMS. Use of propranolol (Inderal) in treatment of hypertension $\mathrm{Br}$ Med $\mathcal{7}$ 1964;2:725-7.

(Accepted 14 fanuary 1981)

\title{
Acute haemolysis due to concentrated dialysis fluid
}

\author{
I MULLIGAN, P PARFREY, M E PHILLIPS, E A BROWN, J R CURTIS
}

\begin{abstract}
Fatal acute haemolysis occurred in a 65-year-old man undergoing regular home haemodialysis for terminal renal failure. Circumstantial evidence indicating that the haemolysis resulted from exposure to concentrated dialysis solution was supported by in-vitro studies. Frank haemolysis in blood samples occurred at a dilution of $>1 / 2$ of dialysis fluid. Osmotic fragility tests of surviving red blood cells showed $47 \%$ haemolysis at a dilution of $1 / 2$ and $>90 \%$ haemolysis at a dilution of $1 / 1$. Urgent design modifications to the proportionating machine are being undertaken to prevent such an accident recurring.
\end{abstract}

Department of Medicine, Charing Cross Hospital Medical School, London W6 8RF

I MULLIGAN, BM, senior house officer

P PARFREY, MD, MRCP, lecturer

M E PHILLIPS, MD, MRCP, senior lecturer

E A BROWN, BM, MRCP, senior registrar

J R CURTIS, MD, FRCP, consultant nephrologist and senior lecturer

\section{Introduction}

Acute haemolysis is a rare complication of haemodialysis. There are a wide variety of medical and drug-related causes of haemolysis which may occur incidentally in patients undergoing maintenance haemodialysis. Several technical causes may also complicate haemodialysis and result in acute haemolysis. These include dialysis against hypotonic dialysis fluid, contamination of dialysis fluid by toxic concentrations of copper, zinc, chloramine, nitrate, and formaldehyde ${ }^{1}$ and haemolysis due to overheated dialysate. ${ }^{2}$ We report the case of a patient who developed acute haemolysis as a result of exposure to very concentrated dialysis fluid.

\section{Case report}

A 65-year-old man had started regular twice weekly haemodialysis in July 1977 because of terminal renal failure due to rapidly progressive glomerulonephritis. He started on home dialysis in May 1978 and dialysed for 10 hours twice weekly using a Meltec Multipoint dialyser $\left(1.05 \mathrm{~m}^{2}\right)$ and a single pass Dylade DII proportionating machine. On the day of admission to hospital in May 1981 
he had started dialysis at home as usual. During the first two hours dialysis was uneventful but a blood-to-dialysate leak developed and he changed to a disposable Gambro dialyser. During the third hour of dialysis the conductivity monitor intermittently registered a high $(+10)$ reading and his attempts to correct this were unsuccessful. $\mathrm{He}$ was then instructed to stop the dialysis but while doing so became unconscious and had several generalised fits. He was admitted to hospital shortly afterwards deeply unconscious and having repeated fits. His blood pressure was $180 / 120 \mathrm{~mm} \mathrm{Hg}$ and he was hyperventilating. The concentration of plasma sodium was $177 \mathrm{mmol}$ $(\mathrm{mEq}) / \mathrm{l}$, potassium $4.9 \mathrm{mmol}(\mathrm{mEq}) / \mathrm{l}$, and blood urea $23 \mathrm{mmol} / \mathrm{l}$ $(138.6 \mathrm{mg} / 100 \mathrm{ml})$. The plasma was grossly haemolysed and the haemoglobin concentration was $5.6 \mathrm{~g} / \mathrm{dl}$ having previously been $9 \mathrm{~g} / \mathrm{dl}$. He was given $10 \mathrm{mg}$ diazepam intravenously and started on haemodialysis immediately. After dialysis for six hours on a Major Gambro dialyser, the plasma sodium concentration had fallen to $143 \mathrm{mmol}(\mathrm{mEq}) / \mathrm{l}$. A dialysis fluid sample from the proportionating machine in his home was analysed and the sodium concentration was found to be $1050 \mathrm{mmol}(\mathrm{mEq}) / 1$ with a potassium concentration of $28.8 \mathrm{mmol}(\mathrm{mEq}) / 1$. His plasma continued to show obvious although decreasing haemolysis over the next three days. He remained unconscious for the next two days. There was a pronounced rise in the serum alanine transferase activity to $740 \mathrm{IU} / \mathrm{l}$ and in the serum inorganic phosphate to $3.7 \mathrm{mmol} / \mathrm{l}(11.46 \mathrm{mg} / 100 \mathrm{ml})$, both returning to normal values in about a week. He slowly improved and two weeks after the accident was conscious, reasonably alert, and could carry on a conversation. He was unable to walk, however. Regular dialysis was continued but over the next month his condition deteriorated. He became completely apathetic with very little spontaneous movement. Serial CT brain scans showed increasing cerebral atrophy. Eventually he was unable to recognise his family, and after full discussion we decided to stop dialysis. He died about two and a half months after the accident. At necropsy there was evidence of acute pancreatitis as well as end-stage kidneys and cerebral atrophy.

Subsequent investigation of the Dylade DII proportionating machine showed that the water supply to the Duplex pump was restricted, which could have resulted in the production of dialysis fluid with an abnormally high conductivity. The machine's conductivity alarm system functioned normally. When triggered the effluent pump stopped and the machine went into bypass. Seepage through the $1 \mathrm{psi}\left(0.07 \mathrm{~kg} / \mathrm{cm}^{2}\right)$ check valve and non-occlusive effluent pump, however, allowed a low flow of dialysis solution of incorrect composition to pass through the dialyser. Urgent design modifications to prevent a recurrence of this situation are being undertaken by the manufacturers.

Results of incubating $1 \mathrm{ml}$ samples of the patient's blood with $1 \mathrm{ml}$ aliquots of dialysis fluid at different dilutions

\begin{tabular}{cccc}
\hline $\begin{array}{c}\text { Dialysis fluid } \\
\text { dilutions }\end{array}$ & $\begin{array}{c}\text { Calculated sodium } \\
\text { concentration in } \\
\text { dialysis fluid } \\
\text { (mmol/l) }\end{array}$ & $\begin{array}{c}\text { Frank } \\
\text { haemolysis }\end{array}$ & $\begin{array}{c}\text { Osmotic fragility } \\
\text { of surviving red } \\
\text { blood cells }(\% \\
\text { haemolysis at } \\
\text { NaCC) }\end{array}$ \\
\hline $1 / 0$ & 4655 & +++ & 90 \\
$1 / 1$ & 2327 & ++ & 96 \\
$1 / 2$ & 1551 & + & 47 \\
$1 / 4$ & 931 & & 1 \\
$1 / 8$ & 517 & & 1 \\
$1 / 12$ & 358 & & 0 \\
$1 / 16$ & 273 & & 1 \\
$1 / 24$ & 186 & & 0 \\
$1 / 32$ & 141 & & 0 \\
$1 / 34$ & 133 & &
\end{tabular}

\section{IN-VITRO STUDIES}

The circumstantial evidence strongly suggested that this patient had been exposed to a concentrated dialysis solution, which was probably responsible for the acute haemolysis. A blood sample was obtained from the patient about two weeks after haemolysis had disappeared and various in-vitro studies were carried out. Serial dilutions of Renalyte $(35 \times$ concentrated dialysis fluid) were made with distilled water. Aliquots of $1 \mathrm{ml}$ of each dilution were then incubated at $37^{\circ} \mathrm{C}$ for 30 minutes with $1 \mathrm{ml}$ of the patient's blood and centrifuged at $5000 \mathrm{rev} / \mathrm{min}$ for 20 minutes. The supernatant was examined for frank haemolysis and then removed. The remaining red blood cells were resuspended in $1 \mathrm{ml}$ normal saline and an osmotic fragility test carried out on the resuspended red blood cells by spectrophotometry. The results are shown in the table. Frank haemolysis was noted in blood samples exposed to dialysis fluid at a concentration of $\geqslant 1 / 2$. Furthermore, the surviving red blood cells exposed to these high concentrations of dialysis fluid showed a pronounced increase in osmotic fragility. In the normal state $0 \%-5 \%$ of red blood cells are haemolysed by $0.5 \%$ saline. In this study surviving red cells which had been exposed to a $1 / 2$ dilution of Renalyte showed $47 \%$ haemolysis and those exposed to a $1 / 1$ dilution $>90 \%$ haemolysis. The precise mechanism of the haemolysis is not clear and, apart from osmotic forces, some of the other constituents of the Renalyte may have contributed to the haemolysis. The composition of undiluted Renalyte is as follows: sodium $4655 \mathrm{mmol}(\mathrm{mEq}) / 1$, potassium $52.5 \mathrm{mmol}$ $(\mathrm{mEq}) / \mathrm{l}$, calcium $52.5 \mathrm{mmol} / \mathrm{l}$, magnesium $17.5 \mathrm{mmol} / \mathrm{l}$, acetate $1365 \mathrm{mmol} / \mathrm{l}$, chloride $3482.5 \mathrm{mmol} / 1$, and dextrose $70 \mathrm{~g} / 1$.

\section{Comment}

To our knowledge this is the first instance of massive haemolysis occurring as a result of exposure to a concentrated dialysis fluid. The in-vitro studies indicated that red blood cells were severely damaged by exposure to such solutions. Haemolysis is not mentioned as a feature of hypernatraemia in the review by Friedler et al. ${ }^{3}$ Furthermore, it did not occur in six patients ${ }^{4}$ who were accidentally exposed to concentrated dialysis fluid, although the sodium concentration in the dialysis fluid was only $215 \mathrm{mmol} / 1$ and the highest serum sodium concentration was $165 \mathrm{mmol}(\mathrm{mEq}) / 1$. In our case study the sodium concentration of the dialysis fluid was $1050 \mathrm{mmol} / \mathrm{l}$, and the patient's plasma sodium on admission was $177 \mathrm{mmol} / \mathrm{l}$. His serum potassium concentration was normal, which is surprising since the samples were haemolysed and the potassium concentration in the dialysis fluid was $28.8 \mathrm{mmol} / \mathrm{l}$. The finding of pancreatitis at necropsy is interesting and may have been related to the acute haemolysis. Walker et $a l^{5}$ have reported two patients being treated with dialysis who developed acute intravascular haemolysis due to exposure to hypotonic dialysis fluid, and in both pancreatitis also occurred.

We thank Mr John Owen, chief medical laboratory scientific officer, Department of Haematology, Charing Cross Hospital, for his help and advice with the osmotic fragility tests.

\section{References}

1 Schuett H, Port FK. Hemolysis in hemodialysis patients. Dialysis and Transplantation 1980;9:345-7.

2 Lynn KL, Boots MA, Mitchell TR. Haemolytic anaemia caused by overheated dialysate. $\mathrm{Br} \mathrm{Med} \mathcal{F} 1979 ; \mathrm{i}: 306-7$.

3 Friedler RM, Koffler A, Kurokawa K. Hyponatraemia and hypernatraemia. Clin Nephrol 1977;7:163-72.

${ }^{4}$ Lindner A, Moskovtchenko JF, Traeger J. Accidental mass hypernatraemia during hemodialysis. Simultaneous observation in six cases. Nephron 1972;9:99-105.

5 Walker JF, Cronin CJ, Donohoe JF, Carmody M, O'Dwyer WF. Acute severe intravascular haemolysis: an unrecognised cause of pancreatitis. Br Med f $1981 ; 282: 1929$.

(Accepted 2 February 1982)

No piece of indolence hurts the health more than the modern cuftom of lying a bed too long in a morning. This is the general practice in great towns. The inhabitants of cities feldom rife before eight or nine o'clock; but the morning is undoubtedly the beft time for exercife, while the ftomach is empty, and the body refref hed with fleep. Befides, the morning air braces and ftrengthens the nerves, and, in fome meafure, anfwers the purpofe of a cold bath. Let any one who has been accuftomed to lie a-bed till eight or nine o'clock, rife by fix or feven, fpend a couple of hours in walking, riding, or any active diverfion without doors, and he will find his fpirits cheerful and ferene through the day, his appetite keen, and his body braced and frengthened. Cuftom foon renders early rifing agreeable, and nothing contributes more to the prefervation of health.

(Buchan's Domestic Medicine, 1786) 